\title{
Blood flow restriction - short insight of the method
}

\author{
Tiberiu PUTA ${ }^{1}$, Alexandra Mihaela STĂNILĂ ${ }^{2}$, Remus DATCU ${ }^{3}$
}

\begin{abstract}
Introduction: The blood flow restriction method is a training method that is based on the partial occlusion of circulation during a workout. This technique combines low-intensity exercise with the occlusion of the bloodstream which produces results similar to high-intensity training. Aim: We aimed to identify the areas in which this method is applicable, its potential benefits and effects, recommendations regarding the rules of use for maximal effects (dosage, intensity, etc.), and also possible contraindications or warnings regarding the use of this method.

Methods: We have analyzed a number of 20 articles on this topic from the field literature of the last 10 years, using "google academic" as a search engine.

Results: After this study we concluded that blood flow restriction is a method with wide applicability in the field of sports training, but also in the recovery process; however, it requires attention in choosing the necessary equipment. For healthy individuals, best training adaptations occur when combining low-load blood flow restriction resistance exercise with traditional high-load resistance exercise. Conclusion: Low-intensity resistance exercise with blood flow restriction is as effective as high-intensity training (for strength and muscle mass gains), but only the high-intensity protocol promotes significant hypotensive responses after exercise.
\end{abstract}

Key words: Blood flow restriction, muscle activation, hypertrophy, strength, rehabilitation

\section{Rezumat}

Introducere: Metoda de restricție a fluxului de sânge este o metodă de antrenament care se bazează pe ocluzia parțială a circulației în timpul unui antrenament. Această tehnică combină exercițiile cu intensitate redusă cu ocluzia fluxului sanguin, ceea ce produce rezultate similare cu antrenamentul de intensitate crescută. Scop: Ne-am propus să identificăm domeniile în care se aplică această metodă, beneficiile și efectele sale potențiale, recomandări privind regulile de utilizare pentru maximizarea efectelor (doză, intensitate etc.) și, de asemenea, posibilele contraindicații sau avertismente cu privire la utilizarea acestei metode.

Metode: Am analizat un număr de 20 de articole pe această temă din literatura de specialite din ultimii 10 ani, folosind "google academic" ca motor de căutare.

Rezultate: După acest studiu am ajuns la concluzia că restricționarea fluxului sanguin este o metodă cu aplicabilitate largă în domeniul antrenamentului sportiv, dar și în procesul de recuperare, dar necesită atenție în alegerea echipamentului necesar. Pentru persoanele sănătoase, cele mai bune adaptări la antrenament apar atunci când exercițiile de forță de intensitate scăzută cu restricția fluxului sanguin sunt combinate cu antrenamentul tradițional de forță, cu încărcătură mare. Concluzie: Antrenamentul de forță de intensitate scăzută cu restricție a fluxului sanguin este la fel de eficient ca și antrenamentul de intensitate ridicată (pentru creșterea forței și a masei musculare), dar numai protocolul de intensitate crescută promovează răspunsuri semnificative hipotensive, după exercițiu fizic.

Cuvinte cheie: Restricția fluxului sanguin, activare musculară, hipertrofie, forță, recuperare

\footnotetext{
${ }^{1}$ Lecturer, PhD, Physical Education and Sport Faculty, West University of Timișoara, Romania

${ }^{2}$ Lecturer, PhD, Physical Education and Sport Faculty, West University of Timișoara, Romania

${ }^{3}$ Assistant Professor, PhD student, Physical Education and Sport Faculty, West University of Timișoara, Romania, e-mail: remus.datcu@euvt.ro
} 


\section{Introduction}

The Blood flow restriction (BFR) method is a training method that is based on the partial occlusion of circulation during a workout. This technique combines low-intensity (LI) exercise with the occlusion of the bloodstream which produces results similar to high-intensity (HI) training $[1,2]$. This method was initially experimented about 40 years ago by Dr. Yoshiaki Sato under the name of kaatsu training (ka-meaning addition and atsupressure) [3].

In the last 20 years, this method has enjoyed increasing attention both in sports performance and in rehabilitation fields.

The BFR method can be used in patients with chronic pain, for postoperative patients, in cases of obesity where HI exercises may not be clinically appropriate, and in conditions that lead to loss of muscle mass, such as cancer, HIV/AIDS., diabetes melitus, etc. [4].

In sports, this method is used for hypertrophy and strength enhancement, development of aerobic capacity, but also in the process of recovering from an accident where the use of large loads is contraindicated.

BFR training, is considered to be a safe and effective method, based on the partial restriction of the venous outflow of an extremity associated with resistance exercises [5].

\section{Methodology}

This review aims to analyze the potential benefits, indications and possible contraindications or warnings regarding the use of this method.

We have analyzed a number of 20 articles from the last 10 years, using "google academic" as a search engine.

We only included in our review studies that used standard cuffs which allow pressure monitoring, considering the simple versions. Special devices created for this method application have a monitor or a screen where the pressure can be tracked, unlike simple pieces of equipment created for gym use [6].

\section{Equipment needed}

The BFR method requires proper but simple equipment: a compression bandage to be placed on a limb and a cuff.

The role of the cuff is to apply a specific pressure that occludes the venous flow while still allowing arterial flow during an exercise. Improvised versions, such as surgical tubing or elastic straps (frequently used as improvisations for the replacement of special sleeves) are not advisable as monitoring the amount of blood flow occlusion is not possible, and the thin diameters of the cuff may cause too much local pressure and, consequently, tissue damage $[6,7]$.

\section{BFR Cuff Width}

A wide cuff is preferred in the correct application of BFR. Usually, cuffs of $10-12 \mathrm{~cm}$ are used. Wide cuffs $(15 \mathrm{~cm})$ may be better for applying uniform pressure. The modern cuffs are adapted to the shape and size of the limbs.

\section{Method presentation}

The literature indicates that the pressure should be applied depending on the width of the cuff that applies the stimulus, as well as the size of the limb on which the stimulus is applied [8].

If cuff size and/or inter-individual differences in limb size are ignored, and pressure is applied based on literature recommendations, the effectiveness and also the safety of the intervention may be affected.

Differences regarding cuff materials can influence the blood flow restriction ability and can also influence the initial pressure (the pressure applied to the limb by the cuff without/prior inflation) [9]. Some studies suggest that standardization of the initial pressure to $50 \mathrm{mmHg}$ with the Kaatsu Master device, and $25 \mathrm{mmHg}$ with the Kaatsu mini, allows for better comparisons across studies [10]. This year (January) in a review on BFR and venous thromboembolism risk, published in "Journal of orthopedic \& sports physical therapy, Bond C.W. et al. presented the following instructions for cuff pressure prescription:

- utilization of a standard pressure (e.g. $180 \mathrm{mmHg}$ ); - establishing a pressure related to the systolic pressure of the patients (e.g. 1.2 - 1.5 times greater than systolic blood pressure);

-pressure must be relative to the patient's limb circumference.

-pressure should be specific (individualized) to each patient - the safest way [11].

\section{How does it work?}

When a muscle is placed under mechanical stress, the release of hormones, hypoxia and cell swelling occur as a result of metabolic stress. These factors are all part of the anabolism of muscle tissue [12]. Blood flow restriction safely reduces venous flow, determining blood to stay in the limbs longer than normal. The local effects of the method include: capillaries lengthen and expand to improve circulation and vascular elasticity, the vascular endothelial growth factor and nitric oxide are produced and lactic acid accumulates in the muscle causing the pituitary gland to secrete growth hormone in large amounts activating the body's metabolism [13]. 


\section{Indications and effects}

As it is well known, performing high load resistance training is the best way to improve muscular strength and obtaining muscle hypertrophy [14].

Basic and usual training recommendations, used for muscle mass and strength gain in healthy individuals, cannot be applied for frail participants, deconditioned or injured athletes [15].

Associated with low-intensity resistance exercise, BFR can determine muscle mass development comparable or even higher than the one obtained with classic strength training [2]. Evidence of studies on this topic shows that alone, or in combination with exercise, BFR has positive effects on muscle size and function $[16,17]$.

The intense muscle activation obtained during the BFR use makes this method appropriate and beneficial for recovery programs, when high loads may be contraindicated [18].

A large number of studies support that BFR used in post-injury recovery or even postoperatively in athletes, speeds up healing accelerating muscular recovery, even using low workload $[5,7,11,18]$.

\section{BFR and exercise-induced muscle damage (EIMD)}

It is well known that EIMD severity is determined by the type (eccentric exercise induces greater EIMD than concentric exercise) and intensity of the exercise [16].

Normally, low-intensity resistance exercise should not determine high levels of EIMD, but some studies have observed that low-intensity resistance concentric exercise with BFR produces greater EIMD than eccentric exercise with BFR and that low-intensity BFR does not result in decreases in force production or increases in creatine kinase (both indirect markers of EIMD) [16].

Most of the studies suggest that BFR combined with low-intensity exercise $\quad \leq \quad 30 \% \quad$ X1-repetition maximum) can increase muscle hypertrophy in the same amount as high-intensity training, avoiding the muscle damage produced by the use of heavy weights $[8,16]$.

These arguments reinforce the view that this type of exercise may be beneficial for older populations, individuals with muscular diseases, or in individuals going through rehabilitation who cannot use high loads to increase muscle size and strength, but according to the study conclusion presented above (if this type of exercise produces significant EIMD during low-intensity resistance exercise), it may not be recommended for people susceptible to muscle damage.

On the other hand, other studies show that soreness is most likely due to the eccentric action of the exercise and not the concentric action. The differences between the results of the studies can be determined by the use of different methodologies and loads. This aspect requires further research to answer the question: Which type of contraction is more efficient and safer in association with BFR? $[16,22]$.

Going further, another question arises: What type of exercise, RT (Resistance training) or AT (Aerobic training), is best in association with BFR?

Resistance training is a form of physical activity that is designed to improve muscular fitness by exercising a muscle or a muscle group against external resistance.

\section{BFT during RT}

The most popular effect of BFT during RT is hypertrophy and muscular strength gain, both in healthy populations and people in the recovery process.

For subjects suffering from heart diseases, the development and maintenance of strength, endurance, power, and muscle mass are essential for reducing and maintaining blood pressure (BP) levels, and that is why RE is used as a strategy to control BP levels

The American Heart Association recommends the RE practice more than aerobic exercise for individuals with coronary disorders because it lowers heart rate and causes lower increases of the double product, but also due to the greater hypotensive response compared to aerobic exercise. A single RE session results in a hypotensive response that can last up to 24 hours.

Both HI and the LI (20 - 50\% X 1RM) + BFR exercise seem to be efficient in maximizing the hypotensive effect associated with RE. Additionally, the LI + BFR protocol can be used to improve diastolic blood pressure and mean blood pressure [23].

A previous study reported that BFR resistance exercise, with LI mechanical load, could improve bone marker in blood level equally to HI resistance exercise, and for this reason, the author considers that BFR resistance exercise may be most beneficial for older people, weak individuals, including patients with chronic heart failure, chronic obstructive pulmonary disease, cancer, and osteoporosis [9, 25].

Muscular stress during RE with BFR differs between sprinters and endurance runners and increasing BFR might affect resistance training in endurance runners, but not in sprinters. Further research on this method should be done in the sports area in order to better understand the mechanism involved and create a proper prescription according to sport specificity. 


\section{BFR during AT}

On the other hand, BFR during low-intensity aerobic training (AT) may not be suited for everyone and must be prescribed carefully according to some studies.

A research team from the Cardiovascular Aging Research Laboratory, Department of Kinesiology and Health Education, from the University of Texas, showed in 2010, that lower limb BFR during lowintensity aerobic exercise, can determine exaggerated increases in blood pressure and cardiac work, and also reductions in systemic arterial compliance, and post-exercise decreases in lower limb endothelial function [24].

These effects may not be appropriate for individuals with compromised cardiac function.

\section{Conclusions and recommendations}

In conclusion, analyzing the field literature we could summarize that:

- It is a method with wide applicability in the field of sports training, but also in the recovery process;

- It requires attention in choosing the necessary equipment (the thickness of the sleeve) and monitoring the pressure applied;

- BFR stimulus should be individualized for each participant according to the restrictive pressure applied and width of the cuff used;

- It combines more effectively with RT than AT

- BFR elicits the largest increases in muscular development when combined with low-load resistance exercise;

- Some benefits may be seen using BFR alone during immobilization or when combined with low-workload cardiovascular exercise;

- For healthy individuals, the best training adaptations occur when combining low-load BFR resistance exercise with traditional highload resistance exercise [25];

- Muscular stress during resistance exercise with BFR differs between sprinters and endurance runners and further studies are needed in order to understand the mechanism involved and the cause of the differences observed;

- LI RE with BFR is as effective as HI training (for strength and muscle mass gains);

- $\quad$ RE with BFR is more recommended in coronary disorders because it lowers heart rate and causes lower increases of the double product, but also due to the greater hypotensive response compared to aerobic exercise;

- Only the high-intensity protocol promotes significant hypotensive responses after exercise.

- $\quad$ RE with BFR can improve bone marker in blood level.

\section{References}

1. VanWye W.R., Weatherholt A.M., Mikesky A.E. (2017). Blood flow restriction training: Implementation into clinical practice, International Journal of Exercise Science, 10(5), 649.

2. Loenneke J.P, Fahs C.A., Rossow L.M., Sherk V.D., Thiebaud R.S., Abe T., Bemben D.A., Bemben M.G. (2012). Effects of cuff width on arterial occlusion: implications for blood flow restricted exercise. European Journal of Applied Physiology, 112(8), 290312.

3. https://www.sportsmed.org/AOSSMIMIS/members/d ownloads/SMU/2017Spring.pdf (accessed on 23 November 2019).

4. Hamilton D.L, MacKenzie M.G., Baar K.R. (2009). Molecular mechanisms of skeletal muscle hypertrophy Using molecular biology to understand muscle growth, accessed on 23 November 2019 from https://www.researchgate.net/publication/23570220 1_Using_molecular_biology_to_understand_muscle_gro wth/stats.

5. Hylden C., Burns T., Stinner D., Owens J., (2015). Blood flow restriction rehabilitation for extremity weakness: a case series, Journal of Special Operations Medicine, 15(1), 50-6.

6. https://www.physiopedia.com/Blood_Flow_Restrictio n_Training:7-15 (accessed on 28 November 2019).

7. McEwen .JA., Owens J.G., Jeyasurya J. (2019). Why is it crucial to use personalized occlusion pressures in blood flow restriction (BFR) rehabilitation?, Journal of Medical and Biological Engineering, 2, 39(2),173-7.

8. Loenneke J.P, Fahs C.A, Rossow L.M., Sherk V.D., Thiebaud R.S., Abe T., Bemben D.A., Bemben M.G. (2012). Effects of cuff width on arterial occlusion: implications for blood flow restricted exercise. European Journal of Applied Physiology, 112, 29032912.

9. Karabulut M., (2011). The effects of different initial restrictive pressures used to reduce blood flow and thigh composition on tissue oxygenation of the quadriceps, Journal of Sports Science, 29, 951-958.

10. Loenneke J. P., Fahs, C. A., Rossow, L. M., Thiebaud, R. S., Mattocks, K. T., Abe, T., \& Bemben, M. G. (2013). Blood flow restriction pressure recommendations: a tale of two cuffs, Frontiers in physiology, 4, 249.

11. Bond C.W., Hackney K.J., Brown S.L., Noonan B.C. (2019). Blood flow restriction resistance exercise as a rehabilitation modality following orthopaedic surgery: A review of venous thromboembolism risk, Journal of Orthopaedic \& Sports Physical Therapy, 49(1),17-27.

12. De Freitas M.C., Gerosa-Neto J., Zanchi N.E., Lira F.S., Rossi FE. (2017). Role of metabolic stress for enhancing muscle adaptations: Practical applications. World journal of methodology, 7(2), 46-54.

13. Rahmani A., Mirzaei B., (2018). The acute effects of resistance exercise with blood flow and respiratory restriction on blood lactate and growth hormone in collegiate. International Journal of Wrestling Science 1, 1,30-35.

14. Chen H.L, Nosaka K., Chen T.C. (2012). Muscle damage protection by low-intensity eccentric contractions remains for 2 weeks but not 3 weeks. European Journal of Applied Physiology, 112, 555-565

15. Thiebaud R.S., Yasuda T., Loenneke J.P., Abe T. (2013). Effects of low-intensity concentric and eccentric exercise combined with blood flow restriction on indices of exercise-induced muscle damage, Interventional Medicine \& Applied Science, 5(2), 53-59. 
16. Loenneke J.P., et. al. (2012). Effects of cuff width on arterial occlusion implications for blood flow restricted exercise. European Journal of Applied Physiology, 112, 2903-2912.

17. Wernbom M., Järrebring R., Andreasson M.A., Augustsson J. (2009). Acute effects of blood flow restriction on muscle activity and endurance during fatiguing dynamic knee extensions at low load, Journal of Strength and Conditioning Research, 23(8), 238995.

18. Takada S., et. al., (2012). Blood flow restriction exercise in sprinters and endurance runners, Medicine and Science in Sports and Exercise, 44(3), 413-9.

19. Umbel J.D., Hoffman R.L., Dearth D.J., Chleboun G.S., Manini T.M., Clark B.C. (2009). Delayed-onset muscle soreness induced by low load blood flow-restricted exercise. European Journal of Applied Physiology 1. 107, 687-695.

20. Wernbom M., Paulsen G., Nilsen T.S., Hisdal J., Raastad T. (2012). Contractile function and sarcolemmal permeability after acute low load resistance exercise with blood flow restriction, European Journal of Applied Physiology, 112, 2051-2063.

21. Loenneke J.P., Wilson J.M., Marín P.J., Zourdos M.C., Bemben M.G. (2011). Low intensity blood flow restriction training: A meta-analysis, European Journal of Applied Physiology, 112, 1849-59.

22. Neto G.R., Sousa M.S., Costa P.B., Salles B.F., Novaes G.S., Novaes J.S. (2015). Hypotensive effects of resistance exercises with Blood Flow Restriction, Journal of strength and conditioning research/National Strength \& Conditioning Association, 29(4),1064-70.

23. Renzi C.P., Tanaka H., Sugawara J. (2009). Effects of leg blood flow restriction during walking on cardiovascular function, Medicine and science in sports and exercise, 42(4), 726-32.

24. Suga T., Okita K., Takada S., Omokawa M., Kadoguchi T., Yokota T., Tsutsui H. (2012). Effect of multiple set on intramuscular metabolic stress during low-intensity resistance exercise with blood flow restriction, European Journal of Applied Physiology, 112(11), 3915-3920.

25. Scott B.R., Loenneke J.P., Slattery K.M., Dascombe B.J. (2014). Exercise with Blood Flow Restriction: An updated evidence-based approach for enhanced muscular development, Sports Medicine, 45(3):313-25. 